Check for updates

University of Bristol, Bristol, UK gabriel.scally@btinternet.com Cite this as: $B M J 2021 ; 374: n 2323$ http://dx.doi.org/10.1136/bmj.n2323 Published: 24 September 2021

\section{England's new Office for Health Improvement and Disparities}

\author{
Terms "health inequalities" and "public health" disappear along with PHE \\ Gabriel Scally visiting professor of public health
}

On 1 October, Public Health England, an executive agency of the UK's Department of Health and Social Care (DHSC), will disappear. Two new organisations will replace it-the Office for Health Improvement and Disparities (to be part of the DHSC) and the UK Health Security Agency (a new executive agency of the DHSC). ${ }^{12}$ What makes these changes notable and concerning is not just the timing, but the disappearance of the words "public health" and the arrival of the phrase "health disparities" (rather than the established term "health inequalities") in the title of the organisation dealing with non-communicable disease. These changes can only reinforce the perception that the government regards activity in the realm of public health as part of an undesirable "nanny state."

Health inequalities have been important and contentious in UK health policy since the publication in 1980 of the Black report on inequalities in health. ${ }^{3}$ Attempts by the UK government to marginalise and suppress attention to health inequalities served only to give the topic prominence. ${ }^{4}$ In the mid-1990s, to dampen persistent academic and public interest in health inequalities, Department of Health civil servants were instructed not to use the term and replace it with "health variation" (personal communication from chief medical officer to regional directors of public health). Despite this, health inequalities remained a key area of research and intervention by academics and public bodies.

Public Health England was created in 2013 as part of substantial health services reforms and took over a range of responsibilities previously carried out by the NHS or independent public bodies. At the beginning of the pandemic, the agency had a crucial role in controlling the spread of SARS-CoV-2. Widespread, but not necessarily fair, criticism of its performance from both within and without government dented its standing, and in August 2020 the government announced its abolition. ${ }^{5}$

In a global infectious disease crisis, things inevitably change in public health. Professionals working in the specialty across the globe have seen an enormous increase in workloads as they strive to bring SARS-CoV-2 under control. Many countries used emergency legislation to extend the powers and responsibilities of specialist public health organisations and boosted resources to control the virus. England did not adopt that approach. Instead, it abolished its national public health body; chose to use commercial sector companies to design, manage, and provide critical public health functions during the pandemic ${ }^{6}$; and repeatedly refused to provide adequate resources to the directors of public health based, with their teams, in local government across England. ${ }^{8}$

The UK was already experiencing a public health crisis before the covid-19 pandemic. The steady improvement in life expectancy, largely uninterrupted during the preceding 100 years, stalled in 2011 and did not resume. ${ }^{9}$ Even more tellingly, the life expectancy of some groups, notably women living in the most deprived local areas, actually started to fall. ${ }^{9}$ The indicator for disability-free life expectancy is even more alarming, with falls for both men and women. Women, in particular, have fared poorly, with a statistically significant drop of more than a year in the most recent data. ${ }^{9}$ Other important indicators of population health (such as infant mortality rates, sexually transmitted diseases, and drug related deaths) show a broadly based public health crisis developing since 2011. ${ }^{10-12}$

As the pandemic was gathering force globally in February 2020, Michael Marmot published a devastating review of health inequalities in England, showing worrying deteriorations in health and widening inequalities since $2010 .{ }^{13}$ His report criticised successive governments for enacting health and social determinants policies that ran counter to the actions needed to improve health equity.

The attempt to replace "inequalities," a term used widely and implying an undesirable situation that should be rectified, with the much less common word "disparities," which at its most basic denotes merely the existence of difference, should be resisted by researchers and practitioners alike. Worsening health inequalities are a blight on England that diminishes us all and suggests a society that has badly neglected its duty to achieve the highest attainable standard of health for all.

Competing interests: I have read and understood BMJ policy on declaration of interests and declare I am a member of Independent SAGE.

Provenance and peer review: Commissioned; not externally peer reviewed.

Department of Health and Social Care. New body to tackle health disparities will launch 10 October, co-headed by new deputy chief medical officer. Press release, 3 Sep 2021. https://www.gov.uk/government/news/new-body-totackle-health-disparities-will-launch-1-october-co-headed-by-new-dcmo-2

2 Scally G. A new public health body for the UK. BMJ2021;373:n875. doi: 10.1136/bmj.n875. pmid: 33795215

3 Department of Health and Social Security. Inequalities in health: report of a research working party. DHHS, 1980

4 Scott-Samuel A, Bambra C, Collins C, Hunter DJ, McCartney G, Smith K. The impact of Thatcherism on health and well-being in Britain. Int J Health Serv2014:44:53-71. doi: 10.2190/HS.44.1.d pmid: 24684084

5 Scally G. The demise of Public Health England. BMJ 2020;370:m3263. doi: 10.1136/bmj.m3263 pmid: 32816779

6 lacobucci G. Covid-19: Government is criticised for "scandalous" $£ 10$ bn spent on test and trace programme. BMJ2020;370:m2805. doi: 10.1136/bmj.m2805. pmid: 32651172 
$7 \quad$ Hurley R. Covid-19: Billions spent on private contracts should have gone to public services, says people's inquiry. BMJ2021;374:n1750. doi: 10.1136/bmj.n1750. pmid: 34244171

8 Association of Directors of Public Health. Statement: responding to the publication of the public health grant allocations. 2021. https://www.adph.org.uk/2021/03/statement-responding-to-thepublication-of-the-public-health-grant-allocations/

9 Office for National Statistics. Health state life expectancies, UK: 2017 to 2019.

https://www.ons.gov.uk/peoplepopulationandcommunity/healthandsocialcare/healthandlifeexpectancies/bulletins/healthstatelifeexpectanciesuk/2017to2019

10 Office for National Statistics. Child and infant mortality in England and Wales: 2019.

https://www.ons.gov.uk/peoplepopulationandcommunity/birthsdeathsandmarriages/deaths/bulletins/childhoodinfantandperinatalmortalityinenglandandwales/2019

11 Public Health England. Sexually transmitted infections and screening for chlamydia in England, 2020. https://assets.publishing.service.gov.uk/government/uploads/system/uploads/attachment_data/file/1015176/STI_NCSP_report_2020.pdf

12 Office for National Statistics. Deaths related to drug poisoning in England and Wales: 2020 registrations. https://www.ons.gov.uk/peoplepopulationandcommunity/birthsdeathsandmarriages/deaths/bulletins/deathsrelatedtodrugpoisoninginenglandandwales/2020

13 Marmot M, Allen J, Boyce T, Goldblatt P, Morrison J. Health equity in England: the Marmot review 10 years on. Health Foundation, 2020. https://www.health.org.uk/publications/reports/the-marmotreview-10-years-on 